Archived version from NCDOCKS Institutional Repository http://libres.uncg.edu/ir/asu/

Reed, Randall W. (2012) "Emerging Treason? Politics and Identity in the Emerging Church Movement", Critical Research on Religion, 2:1 (2014a). The version of record can be accessed from Sage

Publications. [ISSN: 2050-3032], [doi:10.1177/2050303214520777]

\title{
Emerging treason? Politics and identity in the Emerging Church Movement
}

\author{
Randall W. Reed \\ Appalachian State University, Boone, USA
}

\begin{abstract}
The Emerging Church is one of the more interesting new movements in the religious landscape of the United States today. The Emerging Church has come out of US Evangelicalism, which has found itself in crisis, with a diminishing number of young people remaining in the church and a general popular impression of being intolerant, judgmental, and right-wing. Many in the Emerging Church are attempting to construct a vision of Christianity that addresses these problems. However, the Emerging Church is not a monolith; it includes a variety of perspectives and positions. What I will argue in this article is that there is, among several different perspectives within the movement, a critique of the US political and economic system that provides an interesting and new way of thinking about the relationship between Christianity, politics, economics, and identity that may serve to create a challenge to the hegemonic system of the United States. For the purposes of this article I use three examples to illustrate my point: Shane Claibourne's "New Monasticism"/"Red Letter Christians" movement; Brian McLaren's recent work, Why did Jesus, Moses, the Buddha and Mohammed Cross The Road; and Peter Rollins as a self-proclaimed inheritor of the radical tradition. I will show that the Emerging Church thinkers, by challenging the theological constructions of US Evangelicalism, are likewise providing fodder, to varying degrees, for a critique of the US political and economic system. Whether this will coalesce into a real significant challenge or will ultimately be reabsorbed by the status quo and/or marginalized remains to be seen.
\end{abstract}

Keywords

emerging church, identity, Evangelicalism, social theory, politics and religion, religion and postmodernism 


\section{Introduction}

The Emerging Church is one of the more interesting new movements in the religious landscape of the United States today. The Emerging Church has come out of Evangelicalism, which has found itself in crisis, with a diminishing number of young people remaining in the church and a general popular impression of being intolerant, judgmental, and right wing. Many in the Emerging Church are attempting to construct a vision of Christianity that addresses these problems. However, the Emerging Church is not a monolith; it includes a variety of perspectives and positions. ${ }^{1}$ What I will argue is that there is, among the several different perspectives within the Emerging Church movement, a critique of the US political and economic systems ${ }^{2}$ linked to a changing notion of Christian identity that provides its adherents with a new way of thinking about the relationship between Christianity, politics, and economics that may serve to create a religious challenge to US imperialism and, in some cases, to market capitalism.

The Emerging Church comes out of a particular problem within the United States: declining church membership. In the late 1960s and 1970s membership in mainline denominations began to decline, whereas membership in Evangelical churches increased. However, by the 1990s and the beginning of this century the situation had changed, with Evangelical churches now beginning to lose members (Putnam and Campbell, 2010).

This phenomenon was particularly pronounced among the so-called millennial generation-individuals aged 18-29. These individuals were much more likely to drop out of churches than were their parents and grandparents. Additionally, these individuals tend not to just change churches (though some did, which stemmed the flow of exiles from the mainline churches somewhat [Smith and Snell, 2009]), but often to withdraw from organized religion altogether. The trend has been growing. The 2006 Faith Matters Survey found that around a quarter of millennials had dropped out of church (Putnam and Campbell, 2010). In the 2011 follow-up study, the number was much closer to one-third (Putnam and Campbell, 2012). At this rate, it is possible that unchurched millennials may outnumber churched millennials by the end of the decade.

The reasons for this exodus have been studied by a number of scholars. David Kinnaman, in his books Unchristian (2007) and You Lost Me (2011), points to several factors that millennials name for why millennials have withdrawn from organized religion and Evangelical Christianity in particular. Most importantly, millennials criticize the church for being "judgmental," "too political," "homophobic," and "hypocritical." A consensus seems to have arisen among both scholars and Emerging Church leaders that one of the most important factors is the church's rather restrictive perspective on sexuality (Bell, 2012; Kinnaman, 2007, 2011; Smith and Snell, 2009). The negative view of homosexuality and premarital sex has had a significant effect on repelling millennials from church but, as Putnam and Campbell has shown (2010/2012), there is a basic equivalence between political perspective and church, with more conservative political perspectives being attracted to more conservative religious institutions. Some of the loss of membership seems to indicate that young people are unable to find any religious institution that fits them politically. 
The Emerging Church is partially an attempt to answer this problem. Emerging Church thinkers often raise the specter of church membership loss as part of the background for why they have engaged in their theological rethinking (McLaren, 2010; McKnight, 2011), ${ }^{3}$ but they also cite other reasons for their movement. They point to the cultural shift from modernist categories to postmodern ones (McLaren, 2008; Smith, 2006). They claim that there is a hunger for a Christianity which is less conservative politically and more engaged with solving social problems like hunger, poverty, and inequality (Claiborne, 2006). They recognize that an individual's experience of the world can no longer be imagined as homogenous with the influx of people from different cultures and religions into the United States (McLaren, 2012a-d). They can no longer imagine an opposition to science as either workable or honest (McLaren, 2008). Finally, they find the traditional categories of Salvation and Damnation no longer effective in a world where most people's religious inclination is determined by where they are born rather than the compelling nature of religious arguments (Bell, 2011).

The breadth of the Emerging Church is difficult to gauge. Emerging Churches tend to eschew labels, including that of "Emerging Church." James Bielo, in his study Emerging Evangelicals 2011, attempts to compile the best information on numbers of Emerging Churches from some related studies, websites, and organizing groups. In the end, he suggests that although there are various counts of Emerging Churches, cohorts, and groups, all studies fail to give an actual number of participants. What we do know is that groups that can be broadly categorized as Emerging Churches are found across the United States and, as Bielo says, the Emerging Church "is a viable form of identity on the American religious landscape and is present in nearly every region of the United States" (Bielo, 2011: 26).

Likewise, the effect of the Emerging Church is also difficult to estimate. A Google Ngram study shows that the term "Emerging Church" has shown growth since the end of the last millennium, with more rapid increases beginning in 2002 and continuing through the rest of the available data (up to 2008) (Michel et al., 2011). ${ }^{4}$ Although Ngram data should be used carefully, they are useful in revealing cultural trends in published books, and they show the Emerging Church gaining increasing popularity.

Academic approaches to the Emerging Church have highlighted a couple of other items that are important to participants of the Emerging Church. Bielo highlights that the Emerging Church is compelled by a quest for authenticity which entails a critique of consumerism and a focus on changing the world. At the same time there is a postmodern suspicion of the transparency of language. This leads to a rejection of the fundamentalist approach which holds that the Bible can be read by everyone and understood directly (Bielo, 2011). The problem here, of course, is not the liberal or Catholic critique, which demands that the Bible be understood either through the apparatus of historical criticism or tradition, but rather a much deeper problematizing of language itself.

Acknowledging, then, a new postmodern epistemology that is far less certain, the Emerging Church movement has endeavored to reframe Christian and particularly Evangelical theology. To that end the movement has reworked a variety of concepts that are key to its understanding of what a "New Christian" looks like. One of those categories has been the connection between religion, politics, and empire/nationalism. To this end I want to examine the work of three Emerging Church individuals: Shane Claiborne, Brian McLaren, and Peter Rollins. Claiborne is part of the New Monastic and Red Letter Christians (2013) movements ${ }^{5}$ and someone whose work for peace in Iraq has been chronicled by reporter Greg Barrett. McLaren is a significant spokesperson for the 
Emerging Church, who has recently written several e-novellas as well as a book on interreligious dialogue. Rollins, meanwhile, has attempted to translate the work of Slavoj Zizek into a theology for Evangelicalism. Although by many measures these three thinkers may be considered leaders in the Emerging Church movement (book sales, internet presence, conference popularity, etc.), I have chosen these figures more because they show three distinct perspectives concerning the intersection of religion, politics, and identity. ${ }^{6}$ The three Emerging Church thinkers that I have identified here represent a continuum of treason to the US hegemonic structure through the resources of religion and different constructions of identity. In each case, however, I will show that these individuals cast doubt upon the imperialism of the United States and, to varying extents, the Christian endorsement of capitalism. Yet, despite their common concerns, when their solutions are carefully considered and compared, it is apparent that they represent three very different approaches to addressing the larger problems that they all inherently recognize.

These differences can be connected to a battle over the identity of Emerging Church participants. In the three examples examined here, each thinker postulates a different conception of Christian identity for his readers. As different as the political standpoint of each of these thinkers is, each of their perspectives follows from their construction of identity. In order to clarify how I see these thinkers attracting followers, I want to discuss Althusser's example of how this type of identity construction develops. Through Althusser's application of Lacan, he demonstrated that identity is connected to a narrative that interpellates the hearer/reader (Althusser, 1972). The reader/hearer's resonance with the story, a feeling of being "hailed" by it, and the ultimate acknowledgement of a place within that story, is key to the construction of identity. Depending upon the reader/hearer, different identities may be interpellated. Althusser's specific example is of the individual who hears the Christian gospel of God's love/plan that provides redemption for the individual's sin. The individual sees her/ himself exactly in this call and thereby becomes a Christian subject. The thinkers that I will survey in the Emerging Church likewise interpellate the individual. They produce a call in which the individual may identify themselves. If a person does resonate with the particular Emerging Church message, their identity and their subjectivity become constituted by that call. Yet the story told, the call made, the interpellation instantiated, and the identity created are very different for each of these thinkers and have significant differences in terms of social/ political ramifications. Thus these individual theologians constitute a continuum of approaches to Emerging Church identity that is intimately connected to their political/economic reflections and solutions.

\section{Shane Claiborne and the Good Samaritan}

Shane Claiborne is a member of the New Monastic movement. He and several colleagues lived as a religious community in the poorer area of Philadelphia. There, intending to live a sort of primitive Christian communism, they have pooled their resources. Claiborne has authored and co-authored several books, the best known of which is The Irresistible Revolution (2006).

Claiborne spent time in Mother Teresa's homes for orphans and for the dying. His time in Calcutta has clearly had a significant influence on him. Much of his approach is encapsulated in his statement, "Over and over when I ask God why all of these injustices are allowed to exist in the world, I can feel the Spirit whisper to me, 'You tell me why we allow this to happen. You are my body, my hands, my feet'." 
(Claiborne, 2006: 65). This combines with a strategy that is locally based and epitomized in another quote by Mother Teresa which he cites: "We can do no great things, just small things with great love" (Claiborne, 2006: 78). To that end Claiborne's approach is to focus his activities on standing up for social justice in concrete instances like feeding the homeless in a local park, or working for a living wage for custodians at his undergraduate college. His focus is to bring his understanding of the gospel as a dictate towards fairness, social justice, and peacemaking into real situations in his world. At the same time, Claiborne is focused on community building. Claiborne established a communal house where there is a common pool of money for house expenses and "each of us share healthy responsibilities and expectations" (2006: 125). The house is set in the poorer part of Philadelphia and is called "The Simple Way." Claiborne is quite explicit about this experiment, which he calls "the new monasticism." He asserts, "We are forming an alternative culture" (Claiborne, 2006: 147), but it is expressly a separate culture; approvingly he cites Tony Campolo (sociologist at Eastern Seminary), saying "We may live in the best Babylon in the world, but it is still Babylon and we are called to 'come out of her"', (Claiborne, 2006: 196).

He has also been active in foreign policy; in 2003, right before the US invasion of Iraq under George W Bush, Claiborne and several companions went to Iraq under the auspices of the group "Christian Peacemakers." Shane Claiborne's adventures in Iraq have been chronicled by Greg Barrett in The Gospel of Rutba (2012). The book ostensibly tells the story of Claiborne's trip to Iraq to be a "witness for peace." After the "Shock and Awe" campaign that began the war, Claiborne's visit was cut short when one of his colleagues tried to take photographs of the damage done to Baghdad-construed by the Iraqi government as spying. As a result, Claiborne and his comrades were expelled from the country. On the way to the border, the car in which they were riding drove over an improvised explosive device and rolled several times before coming to a stop. All the passengers in the car were injured, some of them critically. They received aid from a group of Iraqis traveling in the opposite direction and were taken to the town of Rutba, which, Barrett explains, was a hotbed of Ba'athist sympathy. Yet despite being Americans-representatives of the nation currently attacking Iraq-Claiborne and his companions had their wounds tended, were treated well, and those who cared for them refused any payment. The story, then, functions as a real-life exemplification of the "Parable of the Good Samaritan," with the Rutba Iraqis playing the part of the Samaritan.

Barrett's book, however, goes beyond this allegorical approach, for in it he details three different kinds of civil disobedience in which Claiborne and his associates engage. The first, of course, is an opposition to the Iraq War. Claiborne is quoted by Barrett at one point (Barrett, 2012: 56): “May we stand by those who face the impending wrath of empire and whisper, 'God loves you, I love you, and if my country bombs your country, I will be right here with you.' Otherwise our gospel has little integrity." But the Iraq War (the United States' involvement in which had ended by the time this book was written) acts as a cipher for all war. War itself is problematic and unbiblical for Barrett (as for Claiborne), who summarizes Paul's message as, "Don't kill, don't steal, don't cheat on your spouse, and most important of all, love your neighbor as yourself ... You cherry pick, nitpick, and tune your ear to Glenn Beck, but that verse still translates into love and peace-loving your neighbor" (Barrett, 2012: 59-60).

Beyond a general pacifist orientation, the book delves into a form of economic pacifism as well, detailing the accounts of several people in Claiborne's circle who have tried to avoid paying taxes that support the war effort. In one case, an individual writes a letter every month to the IRS indicating his refusal to pay a phone tax leveled at the end of the 19th century and which amounts to less than one dollar a 
month. Another individual asks her boss to cut her pay by 75 percent so that she can earn less than the amount required to file their taxes. A third person takes on jobs that lack any paper trail in order not to be tracked by the IRS, and additionally has no bank account, credit cards, or any other kind of account the IRS can attach. At least one person in the story has actually spent time in jail for tax evasion as a result of economic civil disobedience.

It is with this form of economic civil disobedience that there is a subtle, though clearly present, critique of capitalism. In discussing Claiborne, Barrett describes him as someone exposing "the often-toxic trappings of capitalism, the free market, prosperity and upscale know-it-all religion" (Barrett, 2012: 53). Elsewhere, describing Claiborne and his companions' 2010 return to Rutba some seven years after their initial visit, Barrett notes the problem of inconsistent electricity supply to the hospital, commenting: "So, in that way, the faulty electricity is an indirect casualty of war. Of Iraq's new democracy. Of humankind's innate selfishness. Simply capitalism loosed a greater freedom to consume. And with freedom, we have the birth of Rutba's One Percent"' (Barrett, 2012: 130).

The critique of the economic system is implicit in contrast to the overt criticism of the imperialism of US policy in Iraq in the same way as it is implicit in Claiborne's advocacy for the poor and the homeless. This economic critique is leveled through the description of individuals who have opted out of the economic system. Still, although we do not see here a clear analysis of capitalism, what we do see is the valorization of those individuals who have in various ways abandoned capitalism with occasional negative references to the military-industrial complex and war profiteering (Barrett, 2012: 70, 91).

What Claiborne advocates instead is a kind of separation from society. This is seen most recently in his involvement in the Red Letter Christian movement-a movement that attempts to focus on the words of Jesus, particularly from the synoptics. ${ }^{7}$ This means that there is now the inclusion of the Kingdom of God language in Claiborne's critique of society that is absent from much of Protestant theology, which tends to focus far more on Paul and The Gospel of John. For Red Letter Christians the "Kingdom of God" becomes a dominant metaphor for living in the world.

In several stories told by Claiborne there is a political implication to what he does, and often a political intention, but never an actual political agenda. Claiborne will engage in civil disobedience, violating ordinances that threaten to stymie efforts to give food to the homeless or provide shelter in an abandoned church (Claiborne, 2006), but never is there a plan to solve homelessness, or even an attempt to analyze the root causes of it. Claiborne's Kingdom approach is to "act as if" the Kingdom were present and, by believing, make it so.

In fact, one may be somewhat surprised by the political naivety that Claiborne evinces. In one anecdote he relates his role in the college boycott of Taco Bell because of its treatment of immigrant tomato workers (Claiborne, 2006). He narrates with pride the way that Taco Bell ultimately saw the error of its ways and agreed to improve working conditions, but never does he seem to recognize that this boycott was successful precisely because it was targeted at and undertaken by Taco Bell's primary demographic. Anyone who has watched Taco Bell's commercials or seen the campaign for "fourthmeal" (a meal consumed significantly later than the dinner hour) understands that Taco Bell's target demographic is the young adult population. A boycott that comes from that segment of the population (the Taco Bell boycott was organized on college campuses across the United States) is a real threat to Taco Bell's bottom line. Contrast this with the occasional complaint Claiborne lodges against Walmart (Claiborne, 2006; Claiborne and Campolo, 2012). Walmart's demographic is far more diversified and built on poor 
families. As a result they are largely indifferent to the college student's concern, so there is no story of victory over Walmart in Claiborne's work. Oddly enough, though, these connections are never made in Claiborne's writings; Claiborne has no real systemic political or economic critique.

What Claiborne offers instead is essentially a withdrawal from the system. At one point Claiborne discusses a health collective that he participates in. This is a group of some 20,000 members who operate as a self-insured health group. When someone has medical needs, individuals pitch in to pay their hospital bill. Claiborne exalts in this extra system plan as "a beautiful embodiment of a political alternative" (Claiborne and Wilson-Hartgrove, 2009: 79). In Red Letter Revolution (2012) he boasts: "So when someone has a financial need, like the early church, we are going to pool our money together and meet that need ... We have ways of taking care of medical bills when they come up. We have ways of taking care of someone's house if it catches on fire" (Claiborne and Campolo, 2012: 17). Claiborne thus embraces what Roland Boer has labeled (2011) a "Communism of Consumption", which is marked by innovation in the distribution of goods but a failure to address the structural problems stemming from capitalism.

What Claiborne offers instead is a prophetic denunciation of economic and political injustice but with no real plan for change. Take, for instance, Claiborne's performance on Wall Street, in which he and his friends took spare change and coated Wall Street with it. They used dollar bills as confetti and in so doing they proclaimed the year of Jubilee (the Biblical year in which debts were forgiven and ancestral lands restored). They hung signs which urged, "'Share', 'Love' and 'There is enough for everyone's need but not enough for everyone's greed-Gandhi'" (Claiborne, 2006: 189). Clearly, then, here is a denunciation of the capitalist impulse. Claiborne proclaims (2006: 293), "It worked," but it is unclear what "it" was that supposedly "worked" because what Claiborne talks about is "bringing God and mammon face to face," and yet, besides a creative demonstration, there was no program for change. Instead, Claiborne's own analysis of the incident retreats into standard religious language that exhorts, "love can convert hatred, light can overcome darkness, grass can pierce concrete .... even on Wall Street" (2006: 293).

Claiborne instead advocates the Kingdom of God. He comments, "I've always liked the saying, 'Once we really try to love our neighbor as ourselves, capitalism, as we see it, won't be possible and communism won't be necessary"', (Claiborne and Campolo, 2012: 205). In his discussion with Claiborne in Red Letter Revolution, Tony Campolo states their vision clearly:

I have always contended that, figuratively speaking, we are God's underground, struggling for justice and working for the rescue of the planet. And when people scoff and say, "You're far too few and your resources are far too limited," I simply respond, "But we are going to win! We know it doesn't look good right now, but beyond the sky there is a huge invasion force being assembled. We don't know when the signal is going to be given and trumpet sounded, but one day the Church Militant (that's who we Christians are here and now) will be joined by Christ and the Church Triumphant (those who will be resurrected at his coming) and together we will march to victory." We labor, as Paul says so eloquently, not as those without hope, because we believe in this great coming event that we call the Second Coming of Christ.(Claiborne and Campolo, 2012: 252) 
Claiborne responds, "I am reminded of that passage in Romans that speaks of how all creation is groaning for the kingdom ... It continues by saying that 'we ourselves groan inwardly as we wait' (verse 23) [Rom 8:23]. It's an image of groaning, aching, longing" (Claiborne and Campolo, 2012: 254). Campolo and Claiborne agree that the real change that they seek cannot be achieved in this world. That will only come with the second coming, with God's intervention into history in its final act. Certainly they feel compelled to act in the meantime-Claiborne assures his readers, "our waiting is not a passive waiting" (Claiborne and Campolo, 2012: 254), and yet it is waiting nonetheless. True structural change is expected in the future but not through any (human) action in the present.

Thus although one can find in Claiborne's work a critique of both political and economic systems, the emphasis is more on a clear critique of US imperialism, with the Iraq War being the primary example. This political analysis is coupled with criticism of the capitalist system that spreads economic injustice, specifically from the perspective of a Christianity informed by the Emerging Church. This discourse is more activist than theoretical, it lacks a sophisticated ideological analysis, and it is more a naive exposition that says love of neighbor does not equate with killing or exploitation. And yet it stretches slightly beyond that by using the parable of the Good Samaritan to try to humanize the enemy and point out that those of another religion (notably Islam) can be motivated by their religion to compassion as well, and, on the other hand, to oppose the excesses of capitalism through political/prophetic theater, which ultimately demands that believers withdraw from the systems of politics and economics. Such a position, then, may serve ultimately to reinforce the very system of which Claiborne is critical. By refusing to engage systemically, opting instead for withdrawal, Claiborne leaves the system intact for those who do not opt for his extra system solutions.

Intriguingly, all this is connected to Claiborne's construction of Christian identity. The long quote given above is preceded by a connection between the French underground during World War II and the position of the Christian. For Claiborne, then, the Kingdom of God is a government in exile. The ramifications of this for identity are immense. Thus the individual Christian is not an active participant in this world in the same way an expatriate sits on the sidelines in their adopted country. They may in fact feel passionately about the direction that country should take, but they are by definition not political participants. The same can be seen in Claiborne's work. In his book, Jesus for President (2008), Claiborne makes this point several times; most explicitly, he says "the kingdom of God implies a new citizenship, giving Jesus' followers a new identity. If our citizenship is in heaven this should change the way we talk. The word we, if a person is truly born again, will refer to the new people into who a Christian has been born: the church" (Claiborne and Haw, 2008: 295). Here Claiborne intentionally connects the notion of a new Christian identity with a political identity.

The ramifications of just such a move are precisely the kind of solutions that Claiborne suggests. There is no advocating of structural changes to the US political or economic system. Instead, Claiborne is left with the alternative of withdrawal. In some ways this allows him greater freedom, he can go to Iraq during the US invasion, and unite with the people there using this extra-nationalist identity. On the other hand, however, rather than reform or restructure the US delivery of health care, insurance, or public assistance, Claiborne seeks to abandon such systems and engage in extra-structural solutions. Such logic follows from his conception of Christian identity along the model of the expatriate. One cannot stop or change the system-one can only opt out. 
To the extent that there is any kind of political action for Claiborne, it is manifested only as political theater. Part of the implications of the underground movement language above is that no real change can come through actions done in this world. Ultimately, it is the "allied invasion" that will create real change. In the meantime, any political action can only be designed to illuminate and stand for a different way, but cannot be expected to create significant change. Thus, although distributing coins on Wall Street may highlight the greed that is found there, and may help some industrious individuals who sweep up enough to pay for their week's groceries or prescriptions, there is no expectation that economic change will happen or that greed will be exorcised from the system. Instead, a statement has been made "in the meantime."

\section{Brian McLaren and the Word of the Lord}

Brian McLaren is a pioneer in the Emerging Church movement. He is a prolific author who has authored or edited more than twenty books detailing his vision of "A New Kind of Christian." His work integrates an Evangelical background with a postmodern perspective. His books are sometimes fiction (he refers to them as "dialogs" in the Platonic sense), and other times they are straight theology. Most often his work approaches traditional Christian theological categories particularly favored by Evangelicals like soteriology (theology of salvation), eschatology (theology of the end times), atonement (the meaning and appropriation of Jesus death and resurrection), etc. in new ways.

McLaren's position begins with a repudiation of modernist categories. Modernism, which is largely based on industrial analogies like machines and watchmakers, has clouded the Christian message and the interpretation of the Biblical texts. For McLaren, the modernist perspective that has dominated Christianity and reached its apogee in Evangelicalism has now been displaced by post-modern categories. This has tremendous implications for Christian thought and practices. First there is an attempt to reclaim the text as "library" as opposed to "legal constitution" (McLaren, 2010). This leads to a more open reading on a number of issues from homosexuality to other religions. In each case, McLaren seeks to take a perspective that is amenable to change and seeks to encompass a wide variety of people. With the elimination of "proof-texting," McLaren is more focused on what he perceives as the larger overall narrative of the text-one which shows an increasing sensitivity to the needs of the disenfranchised and one which looks to Jesus as an agent of inclusion and change.

In terms of politics, McLaren had previously staked his position in Everything Must Change (McLaren, 2009). In that work he attempts to identify the world's problems and propose solutions. Critiquing the view of the Bible as a "legal constitution," which McLaren argues leads to a significant number of misunderstandings about the text, in Everything Must Change he concludes that many of the world's political issues are the result of a likewise faulty "framing." His term for this phenomenon is "Theocapitalism" (McLaren, 2009: 108). Theocapitalism is capitalism without morals or constraint. McLaren, however, makes it clear that this is not a criticism of capitalism per se:

Again, the problem isn't corporations themselves: the problem is this spiritual ideology of theocapitalism that drives many corporations to live for a single bottom line: profit 
for shareholders, without concern for three other essential bottom lines: the common ecological good, the common social good, and the ultimate good under the gaze of our Creator.(McLaren, 2009: 188)

His focus is not therefore the global corporate/capitalist system, but rather he directs his critique at an ideology that applies to "many" (note, however, not all) and thus is correctible within the system by changing the ideology. The results of maintaining the current ideology are surely destructive (McLaren calls it a "suicide machine") and the crisis severe, but the solution remains for McLaren at the level of ideology. "[I]f we disbelieve the dominant societal system, and if we transfer our trust from its cover curriculum and framing story to the good news of Jesus a radical and transforming hope begins to happen to us" (McLaren, 2009: 281). The language of belief, trust, and story make it clear that what is required here is not a structural revolution (even though McLaren occasionally uses that term) but rather a reformation (specifically of our thinking) based on more ethical principles.

This is not to say that McLaren does not want real change. It is clear particularly in terms of what he terms the "Security System" (which might be more commonly called the "industrial-military complex") that he seeks significant reprioritization away from a war on other countries and more to a war on poverty and sickness and a renewed focus on aid in natural disasters (McLaren, 2009: 170). Yet, in the end, that the system might be repurposed (redeemed?) by its existence is ultimately not questioned, and this pattern holds true for all of McLaren's three systems (security, prosperity, and equity). Even when he recognizes the resultant slums and sweatshops of the third world created by capitalism's unending drum beat of consumption, he still characterizes them as "dysfunctions" (McLaren, 2009: 217), failing to recognize that they are functioning exactly as required in a capitalist system. Although in his discussion of work conditions he actually invokes Marx, the revolution is a threat rather than an answer. In the words of a South African activist whom he cites approvingly, "Marx's prescription was faulty, but at least he diagnosed the problem: the exploited and excluded poor won't abide their marginalization forever" (McLaren, 2009: 224). For McLaren, the choice is thus clear: modification of the system through "the way of 'the Rebel Jesus' or the way of violent revolution" (2009: 224), and that revolution is to be feared-it is not the answer.

Most recently, however, his work has become somewhat more political at the national level, with a series of e-books published in 2012 entitled The Word of the Lord to Democrats (TWLD; McLaren, 2012a), The Word of the Lord to Republicans (TWLR; McLaren, 2012c), and The Word of the Lord to Evangelicals (TWLE; McLaren, 2012b). These books are novellas in which generally an unsuspecting individual is chosen to send a message from God to the group specified in the title. These works offer an important vantage point on McLaren's thought as they explicitly delve into the political-an issue that usually functions only in an ancillary way in his work.

There is no doubt that McLaren is more comfortable on the center-left side of the political spectrum. These books, however, outline a fundamental political/economic critique. In TWLD, the book begins with Rebecca Schwartz receiving a message from God that she writes down and then emails to the mayor of Chicago (Rahm Emmanuel-though not named), who forwards it on to the White House. It consists of a warning that the world will soon reap cataclysmic results of human action for which the divine wishes to send a warning. The problem is boiled down to the fact that, as God says, "Your nation ... does not have a progressive party. Democrats, predictably, will object ... At which objection, the angels here laugh uproariously" (God concludes that although the Republican Party is worse, the 
Democrats are "little more than incompetent accomplices to their [Republican] misdeeds" [McLaren, 2012a: 14]).

At one point, the protagonist, Rebecca Schwartz, confronts a right-wing radio talk show host (named Ash Lembruck) with the following question: "What then would you call a system that produces low wages for the vast majority who work the hardest and huge wealth for investors who do relatively little work?" When Lembruck refuses to answer, she tries again, "What would you call a system where the wealthiest make unimaginable wealth not by producing value but by managing and trading other people's debt?" (McLaren, 2012a: 46). On a roll, she continues: "a system that produces short-term profit by liquidating long-term fixed and social assets that could benefit everyone and converting them into short-term profit for the few... .? A system that externalizes expenses in terms of pollution, national debt, and war, inflicting them on the public, while privatizing profits gained at those costs for the select few?" (McLaren, 2012a: 47).

Lembruck responds by calling her "a full-bore socialist-Marxist-communist-collectivist- class-warfareliberal" (McLaren, 2012a: 47). The charge is perhaps overly generous. Although there is a critique here of the effects of the capitalist system, one which hints at the problem, there is not really an attempt to engage with the systematic Marxist critique. However, the language, much of it cribbed from the Occupy movement, is such that it certainly could act as a starting point for that kind of analysis. However, McLaren offers no answers in this book.

Ultimately the book is apocalyptic in tone. In an interview after Schwartz's "message from God" has been picked up by the media, she states: "Imagine a complete financial crash-not only Wall Street crashing, but the ... whole global system ... Imagine an eco logical crash as well" (McLaren, 2012a: 35). Ultimately, then, McLaren's message is aimed at a reformist impulse. He does not call for revolution, the rise of the proletariat, or the redistribution of wealth and public ownership of the means of production. Much like their role in his analysis of global problems, all of these lurk in the offing as the result of said collapse, but are not the solution to the collapse itself. Rather, when McLaren speaks of solutions he does so in oblique ways, as though just the realization of the necessity of a solution in light of coming disaster will be enough to change the course of history. But what that change should look like remains vague.

Where McLaren is more clear is on the problem of American Exceptionalism (a key issue in the most recent presidential election), which he sees as the root of all other problems. Here the letter from God starts the critique by noting (McLaren, 2012a: 14) that "your nation ... contains exceptional military liabilities (we don't call them 'assets' here) and ... contains exceptional levels of naivete and arrogance (these are the main sources of exceptionalism)." In the interview Schwartz continues this line, noting: "The word of the Lord to the Democrats ... is a word about exceptionalism. If you continue to trumpet the American exceptionalism of the past you're setting up an idol. God's word for that kind of exceptionalism is arrogance, pride, hubris - and that kind of pride goes before only one thing ... [a fall]" (McLaren, 2012a: 35).

In WTLR this sort of criticism continues, but this time focuses on the economy and ecology. Fred Walters is an Ohio farmer who receives a message from the Lord to the Republicans. Through a case of mistaken identity he is able to deliver his message on Fox News, which ends with a shocking proclamation that Republicans are socialists. However, as he later comes to explain, by this he means that Republicans enable corporations in "privatizing profits and socializing costs" (McLaren, 2012b: chap. 12, Loc 500). In 
a later speech, McLaren's main character continues the same kind of assessment made in WTLD, emphasizing inequality and economic injustice. Of course, here again, by calling Republicans "socialists," McLaren thereby serves to foreclose an appeal to socialism as the solution.

In fact the only kind of solution McLaren seems to envision is one founded on individualism rather than collective direct action. In TWLE, Wendy, a Wheaton College student (a well-known Evangelical college), encounters God in three different forms: a homeless man, a single mother, and an abandoned child. In each of these cases, God expresses despair about the negative effect Evangelicals have had on the world. In this book McLaren comes closest to a real economic solution, with Wendy telling a reporter, "Maybe to really help poor people, you have to confront bad economic policies, and maybe that will mean tarnishing the Evangelical image of being-you know, free-market capitalists, and all that" (McLaren, 2012c: ch. 9, Loc 539). Here at least there is talk of confronting capitalism, even if that remains, as in the other examples, vague and undefined.

Still, the book does not end with Wendy engaging in community organizing, or union recruiting, or joining revolutionaries in the jungle, but rather by working as an aid worker in Haiti. Although she has abandoned the notion of salvation as relating strictly to an individual's spiritual status, she still is focused on an individualist solution that changes the world by helping one person at a time rather than fomenting collective action. And this, I would argue, is the basic problem with McLaren's work. Although he sees the problem of the capitalist system in its exploitation and systematic deprivation of the working classes, because he is reformist minded, because he remains in the Evangelical mindset of individualism when it comes to economics, and because he has demonized socialism itself, he cannot offer a real economic solution. He skates perilously close at times to a larger economic critique, but ultimately is unable to go the whole way.

Here, too, the issue of identity is once again an important indicator of where McLaren ends up. He is clearly suspicious of partisan identity, calling for a pox on both Republicans and Democrats. Likewise, his condemnation of American exceptionalism seems to call into question the abusive potential of nationalist identity. Yet, unlike Claiborne, who opts out of the political system completely, McLaren's reformist perspective requires that he remain engaged in the political process. His perspective is more akin to a message of "turn and repent" rather than "this world is not our home." Such a perspective is consonant with his latest work, which self-consciously addresses the question of religious identity.

On 11 September 2012, Brian McLaren (2012d) came out with a new book entitled, why did Jesus, Moses, the Buddha, and Mohammed Cross the Road? Christian Identity in a MultiFaith World. The book takes as its starting point the problem of identity. In the first part, McLaren notes, "An internal unrest about your Christian identity may have factored in your decision to open this book ... More and more of us are seeking treatment for what we might call Conflicted Religious Identity Syndrome (CRIS)" (McLaren, 2012d: 15). This syndrome, McLaren suggests, is constituted by dissatisfaction with and/or outright rejection of much of what has been done and is being done in the name of Christianity. Following James Alison, he anchors the problem in "oppositional identity," described as "we oppose, therefore we are or we know who we are because we know whom we oppose... ." (McLaren, 2012d: 20). McLaren's solution is to rediscover the Christian identity but in a new key. Thus Christian identity must be "redeemed and transformed into what we need" (McLaren, 2012d: 67). What McLaren has in mind is a rethinking of Christian doctrine, liturgy, and practice that is much more informed by relationships than by exclusivist doctrinal stances. Thus, when he reconceptualizes the Trinity (the 
notion that there are three persons in one God), the three persons are all in relationship with one another, rather than different modes or manifestations. When thinking about predestination (the idea that God choose or "elects" individuals to become believers), the notion of chosenness is reformed to be not a privilege that comes with, or results from, being saved, but a responsibility to benefit the world. His Christology (the doctrine dealing with the nature of Jesus) likewise talks about Jesus as "a radically new vision of God, a nonviolent God, a suffering and serving God"' (McLaren, 2012d: 143).

Even more interestingly, and where it seems his view of multi-religious dialog really takes shape, is in his discussion of pneumatology - the doctrine of the Holy Spirit. McLaren states quite clearly, "The Holy Spirit preexists all religions, cannot be contained by any single religion, and therefore can't be claimed as private property by any one religion" (2012d: 150). Instead, then, every religion has "a unique, particular and evolving perspective from which to encounter the Spirit in a unique way" (McLaren, 2012d: 151). For McLaren, every religion, then, can claim a localized experience of the Spirit, which thus by being shared and accepted can add to humankind's understanding and collective knowledge of God. The ramification of such an idea, then, is that Christian identity still has a place, in that a Christian experience of the Spirit is also a part of the collective knowledge, but at the same time it entails that "other religions have something to offer us as well, based on their real and unique encounters with the spirit" (McLaren, 2012d: 152). In his attempt to preserve a role for Christian identity he carves out a place for all religious identities.

I would suggest that what is clear here is that McLaren wishes to reform religious identity in a similar way to his reform of political identity. Like in Claiborne's work, the Christian identity remains paramount, but for McLaren is one which is engaged in the midst of the system. The Christian identity no longer claims exclusive legitimacy, nor is it on the sidelines awaiting some sort of future validation; rather it is one which is constantly engaged with other perspectives. It is willing to grant authority to other religions, but is always in the middle of an on-going discussion and negotiation. It is a form of identity that is willing to give and take but on an equal footing. To this end it is marked both politically and religiously by engagement, but it is also marked by constraint. In the same way it will not challenge other religious claims in exchange for its own claims being left alone, and it likewise is not interested in widespread structural change. It will leave things largely as they are, only asking for a voice and a seat at the table. On the other hand, it harbors no visions of apocalyptic transformation-only slow, incremental change.

\section{Peter Rollins and the Abolition of Identity}

Peter Rollins is, in my view, one of the most interesting thinkers in the Emerging Church movement today. Originally from Belfast, Ireland, Rollins, along with several others, gained notoriety with a series of liturgical experiments called "Ikon." These experiments often called into question traditional Evangelical ideas with a combination of performance art, audience participation, and the use of unusual spaces (like pubs and warehouses), coupled with traditional liturgical elements. He, along with Ikon, gained prominence in the Emerging Church as a result of these experiments. Rollins himself, as a student of continental philosophy, has distinguished himself beyond Ikon by translating the ideas of Slavoj Zizek into Evangelical theology. ${ }^{8}$ He has since become a popular speaker at 
Emerging Church gatherings like Wild Goose, Subverting the Norm, and the "Poets, Prophets and Preachers" conference. His perspective stems from the Marxist and radical theological traditions and thus offers a very different understanding of Christian identity and political engagement. His experience growing up in Northern Ireland during a time of conflict has given him a unique perspective that makes him a distinctive voice in the Emerging Church.

In a number of ways Peter Rollins' work is much less ambiguous than any of the other thinkers that we have heretofore addressed. Because he grounds himself in the Marxist tradition there is no question about whether he has a sustained economic critique. Unlike McLaren, who sees answers only in individualist reformism, Rollins speaks to the larger structural issues, saying,

donating money to the poor without asking why the poor exist in the first place, for instance, allows us to alleviate our guilt without fundamentally challenging the system that perpetuates poverty. As the Brazilian archbishop Dom Helder Camara once said, "When I give food to the poor, they call me a saint. When I ask why the poor have no food, they call me a communist."(Rollins, 2011: 170-171)

Rollins, then, understands that the economic social problem is structural and collective, yet perpetuated by individual action that seeks to do exactly what McLaren seems to advocate: make individual changes without addressing the systemic inequity built into the capitalist system.

One of those systems which functions to perpetuate the status quo for Rollins is, in fact, the church itself, and most importantly the church's suppression of real doubt. Rollins sees even here a structural aspect. The individual is free to have their own private doubts, provided that such doubt is not reflected in the church hierarchy. It is unacceptable for the pastor to express doubts publicly as the pastor functions to believe for the congregation (Rollins, 2011: 85). As long as the structure is in place, doubt does not actually threaten the church. In the same way, dissent is built into the capitalist system. As long as it stays individualist and reformist it does not actually threaten the structure. Instead, such builtin individualist doubt functions as an important part of the system itself. The recognition of this, then, mandates an examination of answers and questions outside the individualist/ reformist perspective.

Because of this structuralist perspective, Rollins rarely addresses the kind of individual problems that we see in either McLaren or Claiborne. He has, instead, a broader sweep in his political vision. Often, therefore, his points are made through analogy and example. For instance, in Insurrection, Rollins notes the problem of the Batman character (2011: 160). Batman continually fights crime by investing hundreds of millions of dollars in military-grade equipment. It is the inherent irony of Batman that instead of Wayne Industries plowing its profits into better schools, worker retraining, and ways of reducing the criminal population, the money is spent equipping the crime fighter. As a result of this corporate negligence there exists a nearly inexhaustible underclass that can be marshaled by Batman's arch-enemy the Joker. Thus Batman as Bruce Wayne feeds a structure that produces a society that needs someone like Batman. Inherent in this critique, Rollins condemns things like greed, poverty, capitalism, and exploitation of the poor. Yet Rollins' critique is such that he asserts that these things are not problems in themselves, but rather the symptomatic manifestations of a political and economic structure.

In engaging in this kind of critique, Rollins takes on the question of Christian identity directly. He sees the issue of identity as a core problem which Christianity solves. Focusing on the famous passage in 
Galatians 3, "In Christ there is neither Jew nor Greek, slave nor free, male nor female [Gal 3:28]," Rollins goes further: "In the community founded on Christ, there is neither black nor white, neither rich nor poor, neither powerful nor powerless. More than this we can add there is neither Republican nor Democrat, liberal nor conservative, orthodox nor heretic" (Rollins, 2011: 185), but Rollins pursues this further to suggest that this doctrine of Christianity requires the dissolution of identity itself. It is not that one eliminates these other identities to now take up a master identity, that of Christian, but, rather, that the demanded abandonment of identities now includes one more-Christian: "The Christian community is not distinct because it embraced yet another identity, but rather is unique in the way that its members lay down the various identities that would otherwise define them" (Rollins, 2011: 186). For him, uniting with Christ eliminates all divisions based on constructed distinctions. Rollins summarizes: "in this way we can read Paul's statement in the book of Galatians as a description of how, in the very act of becoming nothing, we identify with Christ. We can even say that in Christ there is neither Christian nor non-Christian." (Rollins, 2011: 188). Thus, for Rollins there is a complete breakdown of the various constructions of identity in order to be a Christian. ${ }^{9}$

The political implications of this are, of course, large for Rollins. Gone is any notion of being a particular nationality, along with notions of national exceptionalism. With the notion of identity as a way of particularizing an individual removed, there is a reconsideration of precisely the sort of "oppositional hostility" that McLaren discussed. For Rollins, then, the focus is now on the material reality rather than classifications of identity. If we are no longer fighting for "us" or against "them" but are cognizant only of the material world and its implications, then ethical action must be predicated upon material reality. Theology that stems from this must likewise focus strictly on the material. Rollins refers to this as "theological materialism: It is that which transforms our material existence" (2011: 175). ${ }^{10}$ Couple this with Rollin's structural analysis, and what we see is a critique of both the US political and economic systems that demands real political/economic change-a critique that is not content with reformism but uses the resources of Evangelical Christianity to marshal an argument for sweeping political/economic change-in a word, a Christian argument for treason.

This perspective on identity contrasts informatively with that of McLaren. It is interesting that in McLaren's book on religious pluralism he actually cites Rollins on identity. Yet intriguingly he does so in a section on Baptism. For McLaren, then, by placing this in the context of a ritual, this idea of the dissolution of identity becomes a temporary state that then transitions into a new Christian identityone with a broader "solidarity of human kindness, shared with everyone" (McLaren, 2012d: 187) -and yet for McLaren identity continues to be an essential component of Christianity. Granted, it is a more pluralistic embracing of identity, but an identity nonetheless. Rollins, in turn, as we have seen, rejects the very foundation of this idea.

Yet Rollins speaks rarely about what sort of political response is required. At one point in Insurrection he toys with the notion of "Pirate Islands" - places within the world that reject the structure of the world (Rollins, 2011: 170), and yet, seemingly recognizing that such an approach results in withdrawal rather than transformation, he quickly dispenses with the idea. The real solution is one of revolution, yet although Rollins occasionally speaks of revolution-he notes that revolutionaries are always "untimely" - he never speaks for revolution (2011: 192). It would seem, then, that the political ramifications of his positions remain purposely vague. 


\section{Conclusion}

What we have seen, then, is that the Emerging Church has produced a continuum of political/economic critique. For Shane Claiborne and Greg Barrett the politics of empire and the publicly funded war machine create a world where the best solution is a form of withdrawal coupled with individuals crossing boundaries to share human experiences and stories. There is a clear critique of the political situation but one which is only nascently connected to economics.

On the other hand, Brian McLaren has a clear understanding of both the political and economic failings of the US system. The economic inequality that capitalism has generated, coupled with political gridlock and a lack of accountability, has created a world which is no longer acceptable to Christians. It has created a problem of hostile identity, exclusivism, and exceptionalism that threaten our world. Yet the problem for McLaren is not systemic but rather a problem of excess. To that end the solutions that he proposes are not collective; rather, they are reformist and individual. One might suggest that he has correctly identified the symptoms but incorrectly diagnosed the disease.

In both the cases of Claiborne and McLaren, what we see is that their solutions do not lead to serious structural change. What results, then, from each of their critiques is a reaffirmation of the current system either by leaving it in charge (as Claiborne does) or by seeing it as in need of more ethical modification (as McLaren does). The end result is either implicitly or explicitly supporting the status quo.

In contrast to both these thinkers, Peter Rollins sets a new course. By seeing the problems of the church, politics, and economics as forms of connected and similarly constructed structures, he focuses attention on the systemic and foundational problems created by what Althusser would call "Ideological State Apparatuses" (Althusser, 1972). Change in this case does not come from reforming the system but rather from a wholesale repudiation and transformation of the system. Rollins sees Christianity, interpreted through a Zizekian lens, as the way to break down these structures of identity and a capitalist economy through a new materialist theology.

These three perspectives offer a variety of choices for ways Evangelicals might address the problem of political change. What is clear in each case is that all three want to contest nationalistic boundaries and identities. Although they may have more and less clarity about the connection between economics and politics, they nonetheless see that American exceptionalism and its concomitant politics of empire is inconsistent with their understanding of Christianity. In different ways they argue for an abandonment of patriotism and allegiance to US values, arguing in each case for a new perspective that could serve to disrupt American power in the service of a new vision of Christianity which is called to "save the world." To this end the political ramifications of the Emerging Church, if it were to connect with those large numbers of young people disaffected by organized religion, may be a radical political realignment. To what extent such change will be connected with structural economic change differs according to the thinker.

In each case, moreover, the economic/political positions of each thinker are connected to their construction of identity. For Claiborne, the model of the underground movement is one that postulates withdrawal from the system and provides instead political theater with no real anticipation of structural change. Claiborne's solution in the long run is, on the one hand, magical (by doing things differently things will just change) or, on the other, apocalyptic (the coming invasion), neither of which suggests hope for real change. McLaren likewise also seeks to recast Christian identity, but only in a spiritual way. 
Christianity becomes one witness to the spirit among others, and although this has the practical ramifications of calling American exceptionalism into question, it lacks a means to criticize in a structural way the political/economic structures of the United States and capitalism. Instead, McLaren is reduced to reformist neo-liberal solutions that merely seek to moderate the excesses of capitalism in the United States, but he offers no larger critique. Lastly, Peter Rollins' solution challenges all forms of identity that fail to have material grounding and offers precisely what McLaren and Claiborne do not. By making "Christian" one more identity that Christianity seeks to challenge, he confronts the manufactured nature of identities in general. By refocusing on a "materialist theology," Rollins connects identity to economics, where the artificial identities of capitalism are replaced strictly by materialist notions and structural change becomes mandated theologically. To this end, Rollins is able to engage in a structural critique of the religious, political, and economic systems in the United States by essentially placing them all in same arena. This is not possible for Claiborne or McLaren, as both of them seek to elevate the identity of "Christian" as the master identity.

The battle within the Emerging Church is thus ultimately a battle over identity. Different ways of constructing identity lead to differing religious, political, and economic solutions. As Althusser might suggest, the kinds of narratives that these Emerging Church thinkers construct would interpellate individuals, who would then adopt the identity constructions proposed. Depending on the interpellated identity, different political and economic courses of action would be undertaken. What Althusser could not say was why some individuals would be interpellated by one identity over another. ${ }^{11}$ The Emerging Church offers an opportunity for more research in this area. Still to be seen, then, is the effectiveness of these new narratives at interpellating both those who are part of the Christian faith and those who are not or who have left.

\section{Notes}

1. The variety of Emerging Church perspectives is actually quite daunting. Typologies for assessing it have yet to reach consensus. The problem is complicated by the fact that many adherents and churches that might be classified as Emerging eschew labels. James Bielo outlines five "genealogies" that they (mostly) "have internalized and seek to enact" (2011: 16). Yet even here the modifier "mostly" points to the typological problem. Packard likewise established a series of identifiers (organizational structure, modes of worship, and theological beliefs) but notes first that Emerging Church would "best be described as a loosely coupled organization with no distinct leader, vision or mission" (2012: 7). To this end one of the tasks confronting scholars of the Emerging Church is to define it. My own definition follows the assessment of insiders; however, it is also provisional and I hope future work in this area brings greater clarity.

2. The United States is a democratic capitalist society. It is based on laissez-faire capitalism with a minimal social safety net. It is a two-party democracy split between morally conservative, antigovernment Republicans, and more socially conscious Democrats who tend to have a higher opinion about what government can achieve for society as a whole. Although capitalism is unchallenged in the States as the only acceptable economic system, there is much debate over the role of government in both the economic and social spheres. 
3. The declining membership, though cited by Emerging Church thinkers, is not, from their perspective, the primary reason for their work; many of the other factors cited above would rank as more important to them. However, from a sociological point of view, there can be no doubt that the rise of the Emerging Church and the influence they have gained has been facilitated by the decline in church attendance (particularly as it has started impacting Evangelical churches in addition to Mainline churches) and the rise of "nones" (individuals who are choosing "no affiliation" when asked about church membership).

4. The data end at 2008, and so do not take into account 2011, in which the Emerging Church burst on to the popular scene with the publication of Rob Bell's Love Wins. The Emerging Church was afterwards highlighted with articles in the New York Times, Time Magazine, and interviews with Bell on MSNBC and PBS.

5. The Red Letter Christian movement is a group of mostly Evangelical Christians dedicated to the idea of trying to live the ethic portrayed in the Gospels of Jesus. The "red letters" are those words of Jesus often displayed in modern New Testament editions in red. They describe themselves as radicals. The movement's primary leader seems to be Eastern University Professor of Sociology, Tony Campolo, although Claiborne also clearly identifies with them (http://www.redletter christians.org/start/) New Monasticism describes itself as a "movement of Jesus followers who are committed to a new way of life in community" (http://www.newmonasticism.org). It, too, is composed of largely Evangelicals who reject "materialism and the church's complacency toward it," setting up communal living spaces in poor neighborhoods (Moll, 2005).

6. Certainly other individuals could have been chosen-the absence of Rob Bell or Tony Jones is somewhat apparent. The three I have chosen are examples, and they should not be considered representative of the entirety of the Emerging Church; however, I believe that they provide clear examples of the issues at hand. I hope that others might do a similar kind of analysis of other figures in the Emerging Church.

7. I should note here that, much like the Emerging Church generally, the Red Letter Christian movement has a variety of political perspectives inherent within it. Claiborne, however, in concert here with Tony Campolo, represents a significant strain.

8. Rollins is particularly dependent on Zizek's two works dealing explicitly with Christianity: The Puppet and The Dwarf (2003) and The Fragile Absolute (2009).

9. Rollins makes a similar point in his latest work, The Idolatry of God (2013), although in that work there is more ambiguity.

10. Of course, one might worry in two ways about this assertion. First, the dissolution of identity might itself be a kind of marking-a new kind of identity which then fails ultimately to escape the problems that Rollins seeks to solve. More problematically, however, this kind of removal of identity might be subject to the kind of critique that scholars of race have suggested, where "color blindness" serves subtly to reinforce an already existent discriminatory structure. Many oppressed groups feel that their identity is empowering and the removal of such would be a threat to that empowerment. It is perhaps for this reason that, in his most recent work, The Idolatry of God (Rollins, 2013), although not abandoning his call for identity deconstruction, he seems more ambivalent and less clear about the concept than in Insurrection (Rollins, 2011). Katharine Sarah Moody has attempted to reconceptualize 
this as a temporary identity suspension within the liturgical space as one way of addressing this problem, which she argues is provided for in Rollins' work (Moody, 2013).

11. Sociologists and social psychologists working with identity theory have likewise tried to answer this question. They have pointed to things like environment changes, identity conflicts, and social pressures as all part of the solution (Burke and Stets, 2009). Yet these theorists operate at the macro level, and cannot predict what sort of message will appeal to which individuals. 


\section{References}

Althusser L (1972) Lenin and Philosophy, and Other Essays. New York: Monthly Review Press. Barrett G (2012) The Gospel of Rutba: War, Peace, and the Good Samaritan Story in Iraq. Maryknoll, NY: Orbis.

Bell R (2011) Love Wins: A Book About Heaven, Hell, and the Fate of Every Person Who Ever Lived. San Francisco: HarperCollins.

Bell R (2012) Sex God: Exploring the Endless Connections Between Sexuality and Spirituality. Reprint. New York: HarperOne.

Bielo JS (2011) Emerging Evangelicals: Faith, Modernity, and the Desire for Authenticity. New York: NYU Press.

Boer R (2011) Criticism of Religion: On Marxism and Theology, II. Chicago: Haymarket Books. Burke PJ and Stets JE (2009) Identity Theory. Oxford: Oxford University Press.

Claiborne S (2006) The Irresistible Revolution: Living as an Ordinary Radical. Grand Rapids: Zondervan. Claiborne S and Campolo T (2012) Red Letter Revolution: What If Jesus Really Meant What He Said? Nashville: Thomas Nelson.

Claiborne S and Haw C (2008) Jesus for President: Politics for Ordinary Radicals. Grand Rapids: Zondervan.

Claiborne S and Wilson-Hartgrove J (2009) Becoming the Answer to Our Prayers: Prayer for Ordinary Radicals. Downers Grove: InterVarsity Press.

Kinnaman D (2011) You Lost Me: Why Young Christians Are Leaving Church ... and Rethinking Faith. Grand Rapids: Baker Books.

Kinnaman D and Lyons G (2007) Unchristian: What a New Generation Really Thinks About Christianityand Why It Matters. Grand Rapids: Baker Books.

McKnight S (2011) The King Jesus Gospel: The Original Good News Revisited. Grand Rapids: Zondervan.

McLaren BD (2008) A New Kind of Christian: A Tale of Two Friends on a Spiritual Journey. San Francisco: Jossey-Bass.

McLaren BD (2009) Everything Must Change: When the World's Biggest Problems and Jesus' Good News Collide. Nashville: Thomas Nelson.

McLaren BD (2010) A New Kind of Christianity: Ten Questions That Are Transforming the Faith. San Francisco: HarperCollins.

McLaren BD (2012a) The Word of the Lord to Democrats, Kindle Edition. Creative Trust Digital. McLaren BD (2012b) The Word of the Lord to Evangelicals, Kindle Edition. Amazon Digital Services Inc.

McLaren BD (2012c) The Word of the Lord to Republicans, Kindle Edition. Creative Trust Digital. McLaren BD (2012d) Why Did Jesus, Moses, the Buddha, and Mohammed Cross the Road? Christian Identity in a Multi-Faith World. New York: Jericho Books. 
Michel J-B, Shen YK, Aiden AP, Veres A, Gray MK, Pickett JP, et al. (2011) Quantitative analysis of culture using millions of digitized books. Science 331(6014) (14 January): 176-182. Available at:

http://www.sciencemag.org/content/331/6014/176.

Moll R (2005) The New Monasticism: A fresh crop of Christian communities is blossoming in blighted urban settings all over America. Christianity Today. Available at: http://www.christianitytoday. com/ct/2005/september/16.38.html (accessed 6 September 2013).

Moody KS (2013) A new kind of Christian is a new kind of atheist: Psychoanalysis, a/theism and the philosophy and politics of identity suspension. Paper presented at Subverting the Norm II: Can Postmodern Theology Live in the Churches? Drury University, Springfield, MO, 5 April 2013.

Packard J (2012) The Emerging Church: Religion at the Margins. Boulder, CO: Lynne Rienner. Putnam RD and Campbell DE (2010) American Grace: How Religion Divides and Unites Us. New York: Simon \& Schuster.

Putnam RD and Campbell DE (2012) American Grace: How Religion Divides and Unites Us. New York: Simon \& Schuster [first trade paperback edition with new epilogue].

Red Letter Christians (2013). Available at: http://www.redletterchristians.org/start (accessed 6 September 2013).

Rollins P (2011) Insurrection: To Believe Is Human To Doubt, Divine. Carol Stream: Howard Books. Rollins P (2013) The Idolatry of God: Breaking Our Addiction to Certainty and Satisfaction. New York: Howard Books.

Smith C and Snell P (2009) Souls in Transition: The Religious and Spiritual Lives of Emerging Adults. Oxford: Oxford University Press.

Smith JKA (2006) Who's Afraid of Postmodernism? Taking Derrida, Lyotard, and Foucault to Church. Grand Rapids: Baker Academic.

Zizek S (2003) The Puppet and the Dwarf: The Perverse Core of Christianity. Cambridge, MA: MIT Press.

Zizek S (2009) The Fragile Absolute: Or, Why Is the Christian Legacy Worth Fighting For? London: Verso. 